\title{
LEGAL PROTECTON OF WOMEN CIVIL CERVANTS OF GENDER DISCRIMINATION IN THE ERA OF REGIONAL AUTONOMY IN THE DISTRICT ADMINISTRATION SUMBAWA - WEST NUSA TENGGARA
}

\author{
Syarif Dahlan, ${ }^{1)}$ I G. A.A. Ariani, ${ }^{2)}$ I Ketut Wirta Griadhi \\ ${ }^{1)}$ Program Magister Ilmu Hukum Universitas Udayana \\ 2) Hukum dan Masyarakat \\ Email : syarif_dahlan66@yahoo.com
}

\begin{abstract}
Aware of gender discrimintaion of women and students of women in different countries, so they protest and movement finally manage to do some conference that have produced Convention On The Elimination Of All Form Of Diskrimination Against Women (CEDAW). Indonesia has ratified CEDAW with Law No. 7, 1984. But until now gender discrimination still occurs in all facets of life and society. One of them is a fimale civil servant in Sumbawa regency. Discrimination that has accurred not given the opportunity to accupy the fimale civil servant echelon-echelon II and III.

In connection with the second echelon echelon II or III on Sumbawa Regency : 1) What are the forms of gender discrimination against fimale civil servants. 2) What factors are causing it, and 3) What is the form of legal protection against civil servants are women from gender discrimination.

This study includes empirical legal research aims to determine the effectiveness of the law and the legal vacuum in the administration and management of government, particularly in women civil servants in positions echelon II or III. Dates collected were analyzed with descriptive analytic techniques.

These form of discrimination against women in Sumbawa civil servants include marginalization and subordination, the factors that cause it was a mistake in the interpretation and implementation gender equality, influence the understanding and application of Islamic teachings, political and cultural factors shame, geographical factors tough, close relationship with the ruling factor, factor in the civil servants streotif women and a heavier workload factor for women. Moderate forms of legal protection can be seen from the substance of the law, the legal structure and legal culture.
\end{abstract}

Keywords : Llegal protection, gender, fimale civil servants. regional outonomy

I. PENDAHULUAN

Pegawai Negeri Sipil (PNS) perempuan merupakan salah satu kelompok masyarakat yang rentan terhadap perlakuan diskriminatif gender, yang dilakukan oleh pemegang kekuasaan atau pemegang kebijakan. Pada tingkat Kabupaten/kota diskriminasi 
gender yang terjadi khususnya pada jabatan eselon II atau eselon III.

PNS perempuan di pemerintahan Kabupaten Sumbawa masih mengalami perlakuan diskrimintif tersebut. Oleh karena itu penelitian ini berjudul "Perlindungan Hukum Terhadap PNS Perempuan Dari Diskriminasi Gender Untuk Menduduki Jabatan Eselon II atau Eselon III Di Pemerintahan Kabupaten Sumbawa”. Rrumusan masalahnya sebagai berikut : 1).Bagaimana bentuk diskriminasi gender 2). Faktor-faktor apa yang menyebabkan diskriminasi gender 3).Bagaimana bentuk perlindungan hukum tehadap PNS perempuan dari diskriminasi gender.

\section{METODE PENELITIAN}

Jenis penelitian ini adalah penelitian ilmu hukum empiris yaitu penelitian hukum yang langsung mengambil data di lapangan atau pada obyek yang diteliti. ${ }^{1}$ Dalam penelitian hukum empiris ini, yang akan dikaji adalah mengenai diskriminasi gender terhadap PNS perempuan pada posisi jabatan eselon II atau eselon III pada Pemerintahan Kabupaten Sumbawa.

\footnotetext{
${ }^{1}$ Zainuddin Ali.2009. Metode Penelitian Hukum. Jakarta : Sinar Grafika, hal .30.
}

Dilihat dari sifatnya penelitian ini bersifat deskriptif analitik artinya menggambarkan secara tepat dan rinci mengenai sikap, gejala dan keadaan dengan menganalisis secara kritis berdasarkan kajian gender.

Jenis data primer diperoleh dari penelitian lapangan langsung dari sumber pertama, Sedangkan data sekunder diperoleh dari penelitian kepustakaan. Pengumpulan data primer dilakukan dengan teknik wawancara. Teknik mengumpulan data sekunder dengan melakukan studi kepustakaan. Data dianalisis dengan analisis kualitatif, karena penelitian ini bersifat deskriptif.

Penelitian ini berlokasi di Kabupaten Sumbawa Propinsi Nusa Tenggara Barat Dipilih secara porposif, karena Kabupaten Sumbawa didiami oleh masyarakat yang mayoritas beragama Islam sehingga cenderung pada cara berpikir dan budaya patriarkhi dan terletak disebuah wilayah yang jauh dari perkembangan kota besar.

Pengumpulan data primer dalam penelitian ini dilakukan dengan teknik wawancara (interviuw). Wawancara dilakukan langsung di lapangan dengan menggunakan instrument berupa pedoman wawancara (interview guide). Teknik pengumpulan data sekunder adalah dengan melakukan studi kepustakaan 
Informan dan responden sebagai narasumber dalam penelitian ini ditentukan terlebih dahulu sesuai dengan posisi dan kedudukannya dalam struktur organisasi pegawai negeri sipil

Teknik pengolahan data dilakukan dengan langkah-langkah sebagai berikut : Proses editing yaitu merapikan kembali data yang diperoleh dengan memperhatikan kelengkapan, kejelasan dan singkronisasi dari data yang telah dikumpulkan sebelumnya, sehingga dapat diketahui data yang akan digunakan sebagai bahan analisis dan data yang tidak bermanfaat untuk dibuang.

Kemudian dilakukan kualifikasi data yakni mengklasifikasikan jawaban informan dan responden sesuai dengan kriteria yang dibutuhkan. kemudian diolah sehingga data tersebut dapat berfungsi secara relevan dalam menjawab semua permasalahan yang dirumuskan dalam penelitian ini. Analisis data ysng dipergunakan adalah analisis kualitatif, karena penelitian ini bersifat deskriptif. Data kemudian disajikan secara deskriptif kualitatif dan sistematis. Hasil analisis dijabarkan dalam bentuk uraian mengenai fenomena yang diangkat, kemudian dihubungkan dengan teori, konsep dan pendapat sarjana, sehingga diperoleh gambaran yang konprehensif mengenai substansi permasalahan. .

.Dalam penelitian ini teori yang digunakan sebagai pisau analisis adalah :Teori Hukum Alam, Teori Nuture/Nurture, Teori Hukum Feminisme dan Teori Perlindungan Hukum. Hukum Alam menginginkan tidak adanya perbedaan antara laki-laki dan perempuan, sehingga dapat diwujudkan kesetaraan dan keadilan untuk semua manusia tanpa kecuali. Setiap manusia lahir sebagai makhluk ciptaan Tuhan Yang Maha Esa, yang secara kodrati mendapatkan hak dasar yaitu kebebasan, hak hidup, hak untuk dilindungi, dan hak yang lainnya.

Teori nuture memandang adanya perbedaan antara laki-laki dan perempuan merupakan takdir Tuhan, yang mesti diterima manusia sebagai mahluk ciptaannya. Teori nurture memahami bahwa pembahagian kerja secara seksual itu tercipta karena proses belajar dan lingkungan. Artinya perempuan menempati ranah domestik karena diciptakan oleh keluarga, dan masyarakat yang mengesahkan pembagian kerja seperti itu ${ }^{2}$

\footnotetext{
${ }^{2}$ I Gde. Supradnyana Senin 03 Oktober 2011, Pembagian Kerja Secara Seksual
} 
Seorang pemikir hukum feminis dari Universitas Iowa : Patricia A. Cain dalam bukunya yang berjudul Feminist Jurisprudence : Grounding the Theoris mengatakan bahwa "To be considered a feminist, then the theory of law must be based on the experiences of women" (agar dianggap sebagai feminis, maka teori hukum harus didasarkan pada pengalaman perempuan, pengkajian hukum secara feminis bukanlah teori feminis, kecuali didasarkan pada pengalaman perempuan") ${ }^{3}$

Menurut Satijipto Raharjo, perlindungan hukum adalah memberikan pengayoman terhadap hak asasi manusia (HAM) yang dirugikan orang lain dan perlindungan itu di berikan kepada masyarakat agar dapat menikmati semua hak-hak yang diberikan oleh hukum. ${ }^{4}$ Menurut Lili Rasjidi dan I.B Wysa Putra berpendapat bahwa hukum dapat difungsikan untuk mewujudkan perlindungan yang sifatnya tidak sekedar adaptif dan fleksibel, melainkan juga

Berdasarkan Teori Nature Nurture. Dalam igdesupradnyana. blogspot.com/2011/..

${ }^{3}$ Patricia A.Pain,1993.Feminist Yurisprudence Graunding The Theories . Dalam D. Kelly Weistberg (ed.), Feminist Legal Theory, Philadelphia, Temple University Press, hal :35

${ }^{4}$ Satijipto $\quad$ Raharjo, $2000 . \quad$ "Ilmu Hukum', Bandung, PT. Citra Aditya Bakti, hal 53 prediktif

dan antisipatif. ${ }^{5}$

Pendapat Sunaryati Hartono mengatakan bahwa hukum dibutuhkan untuk mereka yang lemah dan belum kuat secara sosial, ekonomi dan politik untuk memperoleh keadilan sosial. ${ }^{6}$

\section{HASIL DAN PEMBAHASAN}

\section{A. Gambaran Umum Kabupaten}

\section{Sumbawa.}

1. Keadaan geografis Kabupaten Sumbawa

. Kabupaten Sumbawa terletak di bagian barat Pulau Sumbawa, berada diantara 116"42'-118"22' bujur Timur. 8".8' $-8 " .7$ ' Lintang Selatan dengan batas-batas wilayah sebagai berikut : sebelah Utara berbatasan dengan Laut Flores; Sebelah Selatan berbatasan dengan Samudera Indonesia Sebelah Timur berbatasan dengan Kabupaten Dompu; Sebelah Barat berbatasan dengn Kabupten Sumbawa Barat.

2. Keadaan Penduduk Kabupaten Sumbawa

5 Lili Rasjidi dan I.B Wysa Putra, 1993“Hukum Sebagai Suatu Sistem”, Bandung : Remaja Rusdakarya, hal. 118

${ }^{6}$ Sunaryati Hartono, 1991 "Politik Hukum Menuju Satu Sistem Hukum Nasional”, Bandung: Alumni, hal. 55 
Populasi suku Sumbawa yang terus berkembang saat ini merupakan campuran antara keturunan etniketnik pendatang atau imigran dari pulau-pulau lain yang telah lama menetap dan mampu beradaptasi dengan lingkungan barunya,

3. Organisasi Pemerintah Kabupaten Sumbawa.

$$
\begin{aligned}
& \text { Secara } \begin{array}{l}
\text { spesifik susunan, } \\
\text { kedudukan tugas dan fungsi }
\end{array} \\
& \text { organisasi pemerintahan } \\
& \text { Kabupaten Sumbawa diatur dalam } \\
& \text { Perda-perda sebagai berikut : }
\end{aligned}
$$
a. Peraturan Daerah Nomor 2 Tahun 2008, tentang Pembentukan, Susunan, Kedudukan, Tugas Pokok Dan Fungsi Sekretaris Deerah dan Sekretaris Dewan Perwakilan Rakyat Daerah Kabupaten Sumbawa, serta Staf Ahli Bupati.

b. Peraturan Daerah Nomor 3 Tahun 2008, Tentang Pembentukan, Susunan, Kedudukan, Tugas Pokok Dan fungsi Dinas Daerah Kabupaten Sumbawa.
c. Peraturan Daerah Nomor 4 Tahun 2008, Tentang

Pembentukan, Susunan, kedudukan, Tugas Pokok Dan Fungsi Lembaga Teknis Daerah Kabupaten Sumbawa

4. Sistem Kekerabatan Masyarakat Kabupaten Sumbawa

Mayoritas masyarakat Sumbawa sampai saat ini memeluk agama Islam. sistem kekerabatan yang dianut oleh masyarakat Sumbawa adalah sistem yang cenderung bersandarkan pada ajaraan Islam, dimana laki-laki dianggap sebagai pemimpin bagi kaum perempuan.

\section{B. Gambaran Umum Tentang Gender dan Diskriminasi Gender}

1. Tinjauan umum mengenai Gender Istilah "gender" dengan pemaknaan seperti yang dipergunakan pada saat ini, pertama kali diperkenalkan oleh Robert Stoller ${ }^{7}$ untuk memisahkan pencirian manusia yang didasarkan pada pendefinisian yang bersifat sosial budaya dengan pendifinisian yang berasal dari ciri-ciri fisik biologis. Gagasan ini dapat dilihat sebagai bagian dari rangkai gagasan

\footnotetext{
${ }^{7}$ Robert Stoller, 1986. Sex And Gender : On
} the Development ofMasculinityand Feminity. London : Hogarth Press. 
yang diperkenalkan oleh Simone de

Beauvoir ditahun 1949 dalam bukunya Le Deuxieme Sexe. ${ }^{8} \quad$ Beauvoir mengemukakan bahwa :"At the same time that womenwith second class citizens in the community as a jew or negra" ( pada waktu itu perempuan sama dengan warga negara kelas dua dalam masyarakat, seperti seorang Yahudi atau Negro).

2. Tinjauan Umum Diskriminasi Gender

$$
\text { Diskriminasi gender }
$$
termanifestasikan dalam berbagai bentuk ketidakadilan, antara lain : subordinasi atau anggapan perempuan tidak penting dilibatkan dalam keputusan politik, marginalisasi atau proses pemiskinan ekonomi, beban kerja lebih panjang dan lebih banyak, dan stereotype atau pelabelan negatif. Sesungguhnya perbedaan gender (gender differences) tidaklah menjadi masalah, sepanjang tidak melahirkan diskriminasi gender (gender inequalities $)^{9}$

\footnotetext{
${ }^{8}$ Simone de Beauvoir, 1964 (1952). The Second Sex. New York : Alfred A Knopf, hal. xiixiv

9 Trisakti Handayani dan Sugiarti, 2008. Konsep Dan Tknik Penelitian Gender. Edisi Revisi Cetakan Ke 2, Malang, UPT Penerbitan Universitas Muhammadiyah Malang,, hal 15
}

\section{Bentuk-bentuk Diskriminasi Gender Terhadap PNS Perempuan Kaitannya Dengan Jabatan Eselon II atau Eselon III Di Pemerintahan Kabupaten Sumbawa.}

\section{Marginalisasi}

Marginalisasi terhadap perempuan dari segi sumbernya bisa disebabkan oleh kebijakan pemerintah, keyakinan, tafsiran agama, keyakinan tradisi, kebiasaan atau bahkan asumsi ilmu pengetahuan. Marginalisasi terhadap perempuan sudah dimulai dalam rumah tangga sampai kepada masyarakat atau kultur dan bahkan oleh negara.

Keadaan PNS perempuan Kabupaten Sumbawa sekarang yang belum mendapatkan posisi setara dengan PNS laki-laki untuk menduduki jabatan eselon II atau eselon III, sesunggunhnya merupakan akibat dari sikap orang-rang tua pada masa lalu, yang menganggap bahwa perempuan tidak penting untuk melanjutkan pendidikan pada tingkat yang lebih tinggi. Sehingga sekarang ini PNS perempuan tidak bisa mengimbangi tingkat kepangkatan dan golongan PNS laki-laki. Walaupun sama-sama senior dalam hal masa kerja, tetapi kalah dalam hal golongan dan pangkat. 
Walaupun sekarang hampir semua PNS sudah mengecap pendidikian di Perguruan tinggi dan sudah sarjana, namun kesarjanaannya terlambat dibandingkan dengan PNS laki-laki.

\section{Subordinasi.}

$$
\text { Konstruksi sosial yang }
$$
menganggap perempuan tidak rasional dan emosional yang menyebabkan perempuan tidak cocok menjadi pemimpin, menjadi penyebab juga bagi PNS perempuan Kabupaten Sumbawa tidak diberikan kesempatan untuk memegang jabatan eselon II atau eselon III. Konstruksi sosial seperti itu menyebabkan terjadinya diskriminasi dalam bentuk subordinasi terhadap PNS perempuan

Hukum alam menginginkan tidak adanya perbedaan antara laki-laki dan perempuan, sehingga dapat diwujudkan keadilan untuk semua manusia tanpa kecuali. Berkaitan dengan hak-hak yang dimiliki manusia secara kodrati, John Locke berpendapat bahwa manusia dalam keadaan bebas dan sederajat, dengan tetap mempunyai hak-hak alamiah yang tidak dapat diserahkan kepada kelompok masyarakat lain, kecuali lewat perjanjian masyarakat ${ }^{10}$

\section{Faktor-faktor Yang Menyebabkan} Diskriminasi GenderTerhadap PNS Perempuan Untuk Menduduki Jabatan Eselon II atau Eselon III Di Pemerintahan Kabupaten Sumbawa

\section{Faktor kesalahan interpretasi dan implementasi kesetaraan dan keadilan gender}

Beberapa kalangan menganggap bahwa kesetaraan gender itu adalah suatu keadaan dimana perempuan mendapat kesempatan untuk bekerja di luar rumah. Ada juga sebagian lainnya yang beranggapan bahwa kesetaraan dan keadilan gender adalah bagaimana laki-laki memahami tugas dan fungsi perempuan. Kesetaraan dan keadilan gender akan terwujud jika laki-laki bisa memberikan kesempatan kepada perempuan untuk bekerja sesuai dengan kemampuan dan keahliannya, tetapi dalam batas-batas tertentu, misalnya tidak boleh melampaui posisi laki-laki, sebagai pemimpin.

10 Mansur. Fakih, 2005. Perkembangan Dimensi Hak Asasi Manusia Dan Proses Dinamika Penyusunan Hukum Hak Asasi Manusia. Surabaya :Ghalia Indonesia, hal :3. 
2. Faktor pemahaman dan penerapan ajaran Agama Islam

\author{
Masyarakat Sumbawa banyak \\ yang beragama Islam. Sehingga \\ pemahamannya terhadap hubungan \\ kerja antara laki-laki dan perempuan \\ berdasarkan pada konsep ajaran \\ Agama Islam. . Selama masih ada laki- \\ laki maka perempuan harus mau terima \\ menjadi anak buah atau bawahan. \\ Apabila tidak maka akan dianggap \\ sebagai melanggar aturan agama.
}

\section{Faktor politik dan budaya malu}

Biasanya PNS perempuan masih sangat memperhatikan budaya malu dibandingkan dengan PNS lakilaki. Malu dalam hal ini yaitu malu mendekatkan diri pada penguasa untuk meminta jabatan. Dengan adanya rasa malu PNS perempuan mendekati penguasa, maka memperkecil peluang atau kemungkinan bagi mereka untuk mendapatkan jabatan.

\section{Faktor geografis yang sulit}

Kabupaten Sumbawa memiliki wilayah yang cukup luas bila dibandingkan dengan luas wilayah yang dimiliki oleh beberapa kabupaten lain yang berada dalam wilayah Nusa Tenggara Barat. Jarak antara pusat kecamatan dengan pusat pemerintahan kabupaten ada yang ditempuh dengan menghabiskan waktu selama 4 sampai 5 jam.

\section{Faktor kedekatan hubungan dengan penguasa}

Kedekatan hubungan yang dimaksudkan disini bisa karena adanya hubungan darah, hubungan kekeluargaan atau hubungan karena jasa. Seorang PNS bisa saja mendapatkan jabatan Eselon II atau Eselon III karena merupakan sanak family (keluarga) Bupati atau Wakil Bupati, keluarga pejabat yang memiliki kewenangan untuk menentukan jabatan atau karena ada jasa yang sudah diberikan pada waktu-waktu tertentu, misalnya pada saat terjadinya proses politik.

\section{Faktor pelabelan negatif (Stereotype) terhadap PNS perempuaan.}

Anggapan bahwa perempuan sebagai penanggung jawab dari semua pekerjaan di rumah, ternyata bukan hanya datangnya dari laki-laki saja, tetapi justru kaum perempuan sendiri yang mengakui. Bahkan tidak sedikit perempuan yang menganggap bahwa mereka bekerja sebagai PNS tidak lain 
tujuannya adalah membantu meringankan beban suami.

\section{Beban kerja lebih berat pada PNS perempuan}

Walaupun perempuan mendapatkan kesempatan untuk bekerja sebagai PNS, namun tidak berarti perempuan tersebut bisa melepaskan diri dari kewajibannya sebagai ibu rumah tangga yang harus menyelesaikan tugas-tugas di rumah Beban kerja ganda inilah yang membuat banyak PNS perempuan dianggap tidak bisa maksimal bekerja untuk memegang jabatan eselon II atau eselon III. Pada sisi lain pekrjaan di rumah juga sudah menunggu untuk diselesaikan.

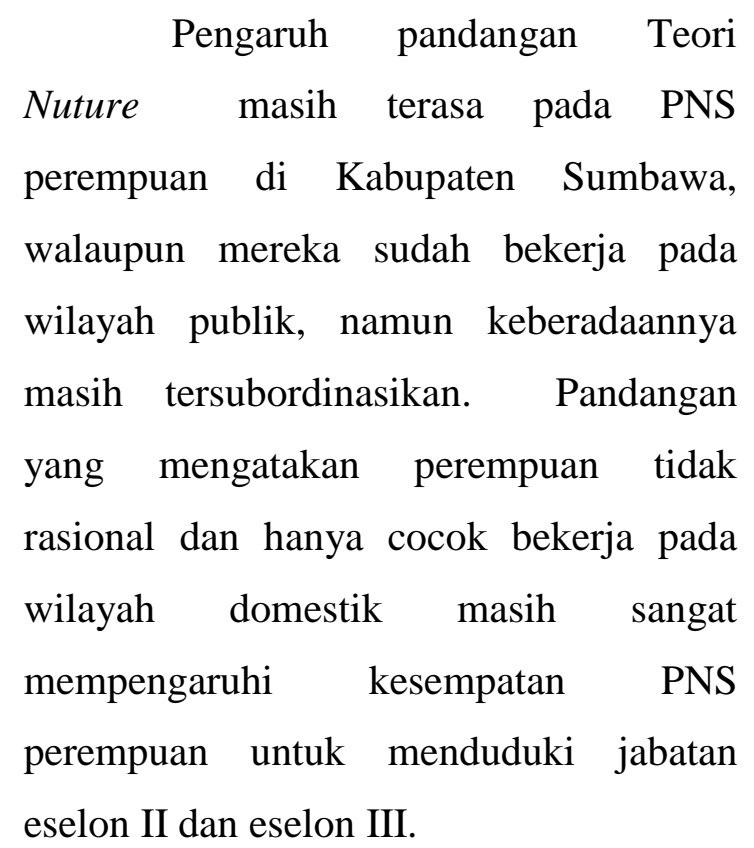


kepegawaian daerah dalam UndangUndang Nomor 32 Tahun 2004 Tentang Pemerintahan Daerah diatur dalam Pasal 129 sampai dengan Pasal 135. Pasal 129 menyebutkan bahwa Ayat (1) : Pemerintah melaksanakan pembinaan manajemen pegawai negeri sipil daerah dalam satu kesatuanpenyelenggaraan manajemen pegawai negeri sipil.

Ayat (2) Manajemen pegawai negeri sipil daerah sebagaimana dimaksud pada ayat (1) meliputi penetapan formasi, pengadaan, pengangkatan, pemindahan, pemberhentian, penetapan pensiun, gaji, tunjangan, kesejahteraan, hak dan kewajiban kedudukan hukum, pengembangan kompetensi, dan pengendaalian jumlah.

Untuk membantu Presiden merumuskan kebijaksanaan kepegawaian dan memberikan pertimbangan tertenntu, Presiden membentuk Badan Kepegawaian Negara sebagaimana diatur dalam Pasal 13 ayat (3) Undang-Undang Nomor 43 Tahun 1999 menyebutkan bahwa : Untuk membantu presiden dalam merumuskan kebijaksanaan sebagaimana disebutkan dalam ayat (2) dan memberikan pertimbangan tertentu, dibentuk Komisi Kepegawaian Negara yang ditetapkan dengan Keputusan Presiden.

Dengan diberikan kewenangan kepada daerah untuk menyelenggarakan manajemen Pegawai Negeri Sipil daerah, maka daerahpun diberikan hak untuk membentuk Badan Kepegawai Daerah (BKD). Pasal 34A ayat (1) dan ayat (2) UU No 43 tahun 1999 menyebutkan bahwa : "Demi kelancaran manajemen kepegawaian daerah, dibentuk Badan Kepegawaian Daerah (BKD). BKD merupakan perangkat daerah otonom yang dibentuk oleh Kepala Daerah. BKD mempunyai tugas pokok untuk melaksanakan tugas bidang administrasi kepegawaian.

Khusus mengenai pengangkatan, pemindahan dan pemberhentian pegawai negeri sipil dari dan dalam jabatan eselon II di Kabupaten/Kota diatur dalam UU No. 32 Tahun 2004 pasal 130 ayat (2), yang menyebutkan bahwa "pengangkatan, pemindahan, dan pemberhentian pegawai negeri sipil dari dan dalam jabatan eselon II pada pemerintahan daerah Kabupaten/Kota ditetapkan oleh Bupati/Walikota setelah berkonsultasi kepada 
Gubernur". Bupati/Walikota merupakan pejabat Pembina Pegawai Negeri Sipil (PNS) di daerah.

Peraturan Pemerintah Nomor 9

Tahun 2003 tentang Wewenang Pengangkatan, Pemindahan dan Pemberhentian Pegawai Negeri Sipil.

Dalam pasal 14 dijelaskan bahwa Bupati/Walikota sebagai pejabat Pembina Kepegawaian Daerah Kabupaten/Kota memiliki kewenangan untuk menetapkan sebagai berikut :

a. Pengangkatan Sekretaris Daerah Kabupaten/Kota setelah mendapat persetujuan dari Pimpinan Dewan Perwakilan Rakyat Daerah Kabupaten/ Kota

b. Pemberhentian Sekretaris Daerah Kabupaten/Kota

c. Pengangkatan, Pemindahan dan Pemberhentian PNS dalam dan dari jabatan struktural eselon II ke bawah di lingkungan Pemerintah Daerah Kabupaten/Kota

d. Pengangkatan, pemindahan, dan pemberhentian PNS dalam dan dari jabatan structural eselon III ke bawah dan jabatan fungsional yang jenjangnya setingkat dengan jabatan structural eselon II ke bawah dilingkungan pemerintah Daerah Kabupaten/Kota.

\section{Perlindungan hukum Terhadap} PNS Perempuan Dari Diskriminasi Gender Untuk Menduduki Jabatan Eselon II atau Eselon III

a. Perlindungan hukum dari sisi substansi hukum.

1).Menurut UU No. 43 Tahun 1999 Tentang Pokok- pokok Kepegawaian

Pasal 1 angka 8 UndangUndang Pokok-Pokok Kepegawaian menjelaskan bahwa: Manajemen PNS adalah keseluruhan upayaupaya untuk meningkatkan efisiensi, efektifitas dan derajat profesionalisme penyelenggaraan tugas, fungsi, dan kewajiban kepegawaian, yang meliputi perencanaan, pengadaan, pengembangan kualitas, penempatan, promosi, penggajian, kesejahteraan dan pemberhentian.

Pasal 17 ayat (2) Undangundang Nomor 43 Tahun 1999 menyebutkan bahwa pengangkatan pegawai negeri sipil dalam jabatan tertentu dilaksanakkan berdasarkan prinsip profesionalisme, sesuai 
dengan kompetensi, prestasi kerja, jenjang pangkat yang ditetapkan untuk jabatan itu, dan syarat obyektif lainnya, tanpa membedakan jenis kelamin, suku agama, rasa atau golongan.

2). Menurut UU No. 39 Tahun 1999 Tentang Hak Asasi Manusia.

Pasal 43 ayat (3) yang berbunyi "setiap warga negara dapat diangkat dalam setiap jabatan pemerintahan".

Pasal 49 ayat (1) berbunyi "wanita berhak untuk memilih, dipilih, diangkat dalam pekerja, jabatan dan profesi, sesuai persyaratan dan peraturan perundang-undangan”. Dalam pasal ini disebutkan secara tegas mengenai hak perempuan untuk mendapatkan jabatan apapun sesuai dengan pesyaratan dan peraturan perundang-undangan yang berlaku. Pasal ini tidak lagi bersifat netral dan obyektif tetapi sudah secara eksplisit menyebutkan hak perempuan untuk dapat menduduki jabatan apapun apabila memenuhi syarat yang ditentukan. Tentunya perempuan yang dimaksud termasuk PNS perempuan yang sudah memenuhi syarat untuk menduduki jabatan eselon II dan eselon III bahkan sebagai kepala kantor.

3). Menurut PP Nomor 100 Tahun 2000 Tentang Pengangkatan Pegawai Negeri Sipil Dalam Jabatan Struktural:

Pasal 4 (1) Pengangkatan, pemindahan, dan pemberhentian Pegawai Negerai Sipil dalam dan dari jabatan struktural ditetapkan dengan keputusan pejabat yang berwenang. (2) Pegawai Negeri Sipil yang diangkat dalam jabatan struktural wajib dilantik dan mengucapkan sumpah dihadapan pejabat yang berwenang.

Pasal 5 Persyaratan untuk dapat diangkat dalam jabatan struktural adalah :

a. Berstatus sebagai Pegawai Negeri Sipil

b. Serendah-rendahnya menduduki pangkat 1 (satu) tingkat di bawah jenjang pangkat yang ditentukan.

c. Memiliki kualifikasi dan tingkat pendidikan yang ditentukan.

d. Semua unsur penilaian prestasi kerja sekurang-kurangnya bernilai baik dalam 2 (dua) tahun terakhir. 
e. Memiliki kompetensi jabatan yang ditentukan.

f. Sehat jasmani dan rohani.

Pasal 6 : Di sampiang persyaratan yang ditentukan dalam pasal 5, Pejabat Pembina Kepegawaian Pusat dan Pejabat Pembina Kepegawaian Daerah perlu memperhatikan faktor senioritas dalam pengangkatan, usia, pendidikan dan pelatihan jabatan, dan pengalaman yang dimiliki.

b. Perlindungan hukum dari sisi struktur hukum

\section{Di Kabupaten Sumbawa} perlindungan terhadap PNS perempuan dari Bupati dan jajarannya belum kelihatan. Pengimplementasian beberapa peraturan perundangundangan yang berkaitan dengan penempatan PNS pada jabatan struktural masih terhalang oleh banyak faktor. Antara lain: faktor kesalahan interpretasi dan implementasi kesetaraan dan keadilan gender. Bupati dan jajarannya memahami kesetaraan gender adalah bagaimana laki-laki memahami perempuan. PNS perempan hanya sebatas dipahami saja, tidak dimanfaatkan untuk kepentingan pembangunan secara maksimal. c. Perlindungan hukum dari sisi budaya hukum.

Budaya hukum merupakan bagian dari sistem hukum. Masyarakat merupakan bagian yang tidak terpisahkan dari penentuan budaya hukum tersebut. Kebiasaan masyarakat dalam menjalankan aturan hukum yang berlaku dalam lingkungannya merupakan cerminan dari budaya hukum masyarakat yang bersangkutan. Budaya hukum adalah nilai-nilai dan sikap yang mengikat sistem itu secara bersama atau menentukan tempat dari sistem hukum itu dalam budaya masyarakat sebagai suatu keseluruhan. Budaya hukum merupakan elemen sikap dan nilai sosial. ${ }^{12}$ Dengan begitu budaya hukum mengacu pada bagian-bagian yang ada pada kultur umum - adat, kebiasaan, opini, cara bertindak dan berpikir - yang mengarahkan kekuatan-kekuatan sosial menuju atau menjauh dari hukum dan dengan cara tertentu. $^{13}$

${ }^{12}$ Lawrence M. Friedman, 1975; dalam The Legal System; A Social Scince Prespective, New York, Russel Sage Foundation, hal : 12-16.

${ }^{13}$ Dennys Lioyd, 1973. The Idea of Law. Harmondsworth. Penguin Books. Hal 100. Dalam Sulistiowati Irianto. 2008, hal : 4 
Konsep obyektifitas dan netralitas hukum berasal dari aliran positifisme hukum, yang beranggapan bahwa kepastian hukum hanya akan terwujud apabila hukum dianggap sebagai sebuah sistem yang tertutup dan otonom dari berbagai persoalan moral, agama, filsafat, politik, sejarah dan lain-lain. Untuk dapat membuat posisi PNS perempuan menduduki jabatan kepala kantor, jabatan eselon II atau eselon III, perlindungan hukum yang dibutuhkan adalah yang beersifat responsive atau memihak, tidak sekedar netral dan obyektif. Pemerintah harus mampu memproduksi peraturan perundangundangan yang secara tegas mengatur berapa besar porsi PNS perempuan, atau dengan langkahlangkah lain yang dapat memberikan kepastian kepada setiap pegawai negeri sipil yang telah memenuhi syarat untuk menduduki jabatanjabatan strategiis tersebut.

Feminis Liberal yang
menekankan bahwa setiap orang
memiliki otonomi termasuk
perempuan. Oleh karena itu antara
PNS laki-laki dan PNS perempuan
harus ada kesetaraan. Karena menurut
aliran ini perempuan dan laki-laki

memiliki rasionalitas yang setara. Jadi antara PNS laki-laki dan PNS perempuan harus mendapatkan kesempatan yang sama untuk menerapkan kemampuan rasionalitasnya.

PNS perempuan menurut sisi pandang feminis liberal memiliki rasionalitas sebagaimana yang dimiliki oleh PNS laki-laki. Oleh karena itu sesuai dengan kerangka kerja feminis liberal yang memperjuangkan persoalan masyarakat pada umumnya sehingga tercapai satu tujuan yaitu kesempatan yang sama dan hak yang sama bagi semua orang, termasuk mendapatkan kesempatan menduduki jabatan kepala kantor atau jabatan eselon II dan eselon III..

\section{P E N U T U P}

\section{A. Simpulan}

Setelah penulis melakukan penelitian terhadap PNS perempuan khususnya yang ada di Kabupaten Sumbawa yang berkaitan dengan telah terjadinya diskriminasi gender dalam mendapakan jabatan sebagai kepala kantor, jabatan eselon II atau eselon III, maka dapat diambil beberapa simpulan, yaitu sebagai berikut : 
1. PNS perempuan di pemerintahan Kabupaten Sumbawa mengalami 2 (dua) macam bentuk diskriminasi gender yaitu : marginalisasi dan subordinasi.

2. Diskriminasi yang dialami oleh PNS perempuan di Kabupaten Sumbawa sehingga tidak bisa menduduki jabatan eselon II atau eselon III disebabkan oleh beberapa factor, antara lan :

a. Kesalah interpretasi dan implementasi kesetaran dan keadilan gender.

b. Pengaruh pemahaman dan penerapan ajaran Agama Islam

c. Pengaruh politik dan budaya malu

d. Faktor geografis Kabupaten Sumbawa yang sangat sulit untuk didatangi.

e. Faktor pelabelan negatif

f. Faktor beban kerja lebih berat.

3. Perlindungan hukum terhadap PNS perempuan dari diskriminasi gender pada pemerintahan Kabupaten berdasarkan pada : a. Undang-undang Nomor 43 Tahun 1999 Tentang Pokok-pokok Kepegawaian.

b. Peraturan Pemerintah Republik Indonesia Nomor 100 Tahun 2000 Tentang Pengangkatan Pegawai Negeri Sipil Dalam Jabatan Struktural

c. UU No. 39 Tahun 1999 Tentang Hak Asasi Manusia.

d. Tiga Perda Kabupaten Sumbawa, antara lain : Perda Nomor 2 Tahun 2008, Perda Nomor 3 Tahun 2008 dan Perda Nomor 4 Tahun 2008.

\section{B. Saran-saran}

1. Agar perempuan tidak selalu didiskriminasikan oleh hukum, maka sebaiknya hukum yang dibuat tidak sekedar netral dan obyektif, tetapi harus betul-betul mencerminkan nilai-nilai feminis.

2. Undang-undang Pokok Kepegawaian yang selama ini diberlakukan sebaiknya dirubah dengan Undang-undang yang baru. Yaitu undang-undang yang didalamnya tidak sekedar netral dan obyektif, tetapi yang betul-betul responsif. 
3. Perlu difahami sekaligus diusahakan agar penerapan nilai-nilai feminis disesuaikan dengan nilai-nilai yang hidudp dalam masyarakat. Kecuali hal-hal yang berkaitan dengan pemanfaatan kemampuan otak, maka kesetaraan antara laki-laki dan perempuan tidak boleh ada tawar menawar.

\section{DAFTAR KEPUSTAKAAN}

Ali, Zainuddin.2009. Metode Penelitian Hukum. Jakarta : Sinar Grafika.

Fakih, Mansur. 2005. Perkembangan Dimensi Hak Asasi Manusia Dan Proses Dinamika Penyusunan Hukum Hak Asasi Manusia. Ghalia Indonesia, Surabaya

Handayani, Trisakti, Dan Sugiarti, 2008. Konsep Dan Tknik Penelitian Gender. Edisi Revisi Cetakan Ke 2, Malang: UPT Penerbitan Universitas Muhammadiyah Malang,.

Hartin, Sri, Setiajeng Kadarsih dan Tedi Sudrajad. 2008. Hukum Kepegawaian Di Indonesia. Sinar Grafika. Jakarta

Hartono, Sunaryati, 1991 "Politik Hukum Menuju Satu Sistem Hukum Nasional”, Bandung: Alumni,

Lioyd, Dennys 1973. The Idea of Law. Harmondsworth. Penguin Books. Hal 100. Dalam Sulistiowati Irianto. 2008M. Hilary, Lipps, 1993.Sex And Gender An Introduction. London, Mayfield Reblishing Company.

Pain, PatriciaA.,1993.Feminist Yurisprudence Graunding The Theories . Dalam D. Kelly Weistberg (ed.),
Feminist Legal Theory, Philadelphia Temple University Press,

Raharjo, Satijipto, 2000. 'Ilmu Hukum', Bandung: PT. Citra Aditya Bakti.

Rasjidi, Lili dan I.B Wysa Putra, 1993"Hukum Sebagai Suatu Sistem”, Bandung : Remaja Rusdakarya

Satoto, Sukamto. 2004.Pengaturan eksistensi dan Fungsi Badan Kepegawaian Negara. HK Offset, Yoyakarta

Supradnyana, I Gde. Senin 03 Oktober 2011, Pembagian Kerja Secara Seksual Berdasarkan Teori Nature Nurture. Dalaam igdesupradnyana. blogspot.com/2011/..

Wilson, HT. 1998. Sex And Gender, Making Kultural Sence.Of Sivilazation. Laden,

Zaitunnah, Subhan, 2007. Rekonstruksi pemahaman Gender Dalam Islam : Agenda Sosio Kultural Dan Politik Peran Perempuan. El Kahfi, Jakarta,

\section{Peraturan Perundang-undangan}

Undang-undang Nomor 32 Tahun 1999 Tentang Pemerintahan Daerah

Undang-undang Nomor 43 Tahun 1999 Tentang Perubahan Atas Undangundang Nomor 8 Tahun 1974 Tentang Pokok-pokok Kepegawaian

Undang-Undang No. 39 Tahun 1999 Tentang Hak Asasi Manusia.

Peraturan Pemerintah Republik Indonesia Nomor 100 Tahun 2000 Tentang Pengangkatan Pegawai Negeri Sipil Dalam Jabatan Struktural

Undang-Undang Republik Indonesia Nomor 23 Tahun 2004 Tentang Penghapusan Kekerasan Dalam Rumah Tangga 
Peraturan Pemerintah Republik Indonesia Nomor 9 Tahun 2003 Tentang Wewenang Pengangkatan Pemindahan Dan Pemberhentian Pegawai Negeri Sipil Dari Jabatan Struktural.

Peraturan Daerah Nomor 2 Tahun 2008, tentang Pembentukan, Susunan, Kedudukan, Tugas Pokok Dan Fungsi Sekretaris Deerah dan Sekretaris Dewan Perwakilan Rakyat Daerah Kabupaten Sumbawa, serta Staf Ahli Bupati.
Peraturan Daerah Nomor 3 Tahun 2008, Tentang Pembentukan, Susunan, Kedudukan, Tugas Pokok Dan fungsi Dinas Daerah Kabupaten Sumbawa.

Peraturan Daerah Nomor 4 Tahun 2008, Tentang Pembentukan, Susunan, Kedudukan, Tugas Pokok Dan Fungsi Lembaga Teknis Daerah Kabupaten Sumbawa 